Check for updates

Cite this: RSC Adv., 2017, 7, 28373

\title{
Changes of mineralogical characteristics and osteoblast activities of raw and processed pyrites
}

\author{
L. Liu, ID $\dagger^{a}$ G. H. Zhao, $\dagger^{a}$ Q. Q. Gao, ${ }^{a}$ Y. J. Chen, ${ }^{c}$ Z. P. Chen, ${ }^{\text {ab }}$ Z. S. Xu*d \\ and W. D. Li ${ }^{\star a b}$
}

Pyrite, a commonly used mineral medicine in traditional Chinese medicine (TCM), is normally prescribed in the form of calcined or processed pyrite to ensure clinical safety and efficacy. We herein compared the changes of mineral phase characteristics of raw and processed pyrites and their effects on osteoblast proliferation. Processed pyrite was fragile and crispy compared to the raw one. Its main component changed from $\mathrm{FeS}_{2}$ to $\mathrm{Fe}_{7} \mathrm{~S}_{8}$. After calcination and quenching in vinegar, the concentrations of $\mathrm{Fe}$ and $\mathrm{Zn}$ increased in the decoction of processed pyrite, whereas that of As decreased. Serum containing processed pyrite enhanced the alkaline phosphatase activity of osteoblasts compared to blank serum, and serum containing raw pyrite also increased such activity. The osteogenesis-enhancing function of processed pyrite was manifested as increased numbers and areas of formed mineralized nodules. The findings are helpful to unveil the clinical mechanism of processed pyrite which has commonly been used to treat bone fracture in TCM practice.

Received 7th April 2017 Accepted 23rd May 2017

DOI: $10.1039 / \mathrm{c} 7 \mathrm{ra03970k}$

rsc.li/rsc-advances should be used after calcination and quenching in vinegar. ${ }^{1}$ According to the TCM processing theory, after being calcined at high temperature and quenched in vinegar as soon as possible, pyrite can be easily crushed, accompanied by reduction of toxic elements and dissolution of effective components in decoction. The surface features of pyrite are changed and toxic elements are reduced after being calcined and quenched in vinegar. ${ }^{6}$ However, previous studies only focused on the changes of mineral phase characteristics of pyrite before and after processing. To the best of our knowledge, the changes of mineral phase characteristics of processed pyrite, or its effects on osteoblast proliferation and differentiation have never been studied hitherto.

Bone fractures are common medical conditions in which the continuity of bones is damaged. Fracture healing is normally a spontaneous process, which can be briefly divided into inflammation, formation of soft and hard calluses, and finally bone remodelling. ${ }^{7}$ If this process does not happen, as in the case of compromised fracture healing or segmental bone defect, surgical or medicinal intervention is required. Medicinal intervention can improve the local environment by providing osteoprogenitor cells, structural substrates and bone-inducing proteins. ${ }^{8}$ New bone formation is primarily mediated by osteoblasts, and bone resorption predominantly depends on the function of osteoclasts. Therefore, during fractured bone remodeling, increasing osteoblast proliferation can enhance bone formation.

We herein aimed to investigate the changes of mineral phase characteristics and mineralogical compositions of processed pyrite, and its effect on osteoblast proliferation. Raw pyrite was
Nanjing, China. E-mail: liweidong0801@163.com

${ }^{b}$ Engineering Center of State Ministry of Education for Standardization of Chinese Medicine Processing, Nanjing University of Chinese Medicine, Nanjing, China

${ }^{c}$ Modern Analysis Center of Nanjing University, Nanjing, China

${ }^{d}$ Wuhu Pure Sunshine Natural Medicine Company Limited, Wuhu, China. E-mail: xuzisheng@hotmail.com

$\dagger$ L. Liu, G. H. Zhao contributed equally to the project and are considered as co-first authors. 
processed at optimized temperature for optimized calcination time to prepare processed pyrite. Scanning electron microscopy (SEM) was applied to detect the variation of microstructure, and the change of mineral phase composition was measured by powder X-ray diffraction (XRD) and infrared (IR) spectroscopy. Magnetic characteristics analysis showed the magnetic changes and magnetic mineral contents of raw and processed pyrites. Inductively coupling plasma atomic emission spectrometry (ICP-AES) was applied to quantify metal elements. In addition, in vitro cell experiment was also conducted to detect osteoblast proliferation, alkaline phosphatase (ALP) activity and bone mineralization activity after treatment with different pyrite samples prepared by various processing methods.

\section{Experimental}

\section{Sample preparation}

Raw pyrite was purchased from Nanjing Haichang Chinese Medicine Group Corporation (Nanjing, China). Sample authentication was conducted by Professor Jianwei Chen of Nanjing University of Traditional Chinese Medicine. Raw pyrite was pulverized into granules with diameters of about 13-16 $\mathrm{mm}$. Processed pyrite was prepared according to the Chinese Pharmacopoeia (2015). In brief, raw pyrite with the thickness of 2-3 cm was calcined at $600{ }^{\circ} \mathrm{C}$ for $2 \mathrm{~h}$ and then quenched in vinegar (100:30, pyrite/vinegar, w/w). Raw and processed pyrites were dried at $80{ }^{\circ} \mathrm{C}$ for $1.5 \mathrm{~h}$ and then stored in desiccator.

\section{Microstructure of pyrite}

The granules of raw and processed pyrites were detected by using SEM to observe microstructural differences.

\section{Mineralogical characteristics of pyrite}

Ore microscope was employed to observe the internal mineralogical changes before and after processing.

\section{Phase composition of pyrite}

Preparation of raw and processed pyrite samples for XRD determination. To analyze the phase composition change of processed pyrite, raw and processed pyrites were separately crushed to powders with diameters of less than $0.074 \mathrm{~mm}$. The phase composition and phase change of raw and processed pyrites were detected by using XRD under the following conditions: $\mathrm{Cu} \mathrm{k} \alpha 1$ radiation, graphite monochromator, $40 \mathrm{kV}$ tube voltage, $200 \mathrm{~mA}$ tube current, 2 theta scanning of $5-85^{\circ}$, scan speed of $5^{\circ} \min ^{-1}$, DS (slit) launch $=$ SS (scattering slit prevention $)=1^{\circ}$, and RS (receiving slit) $=0.15 \mathrm{~mm}$.

Preparation of raw and processed pyrite samples for IR analysis. Raw and processed pyrites were separately crushed into powders with diameters of less than $0.074 \mathrm{~mm}$. The obtained powders were mixed with $\mathrm{KBr}$ respectively in a ratio of $1: 200$, ground to smooth, and finally compressed to a transparent sheet before IR detection in the range of 4000-400 $\mathrm{cm}^{-1}$. Each sample was scanned 16 times. OMNIC 32.0 was used to process the data.
Preparation of raw and processed pyrite samples for magnetic characteristics analysis. Raw and processed pyrites were separately crushed to powders with diameters of less than $0.074 \mathrm{~mm}$. For each sample, $5 \mathrm{mg}$ was applied on the sealing tape and detected by using a vibrating samples magnetometer in the range of $-10^{4}$ Oe to $10^{4}$ Oe. The sensitivity was set at $10^{-7}$ emu.

\section{Trace element determination}

Pyrite mainly contains $\mathrm{FeS}_{2}$. In the meantime, it also contains scarce amounts of magnesium, calcium and zinc, and trace amounts of nickel, arsenic, manganese, barium, copper, etc. ${ }^{2}$ In this study, ICP-AES was utilized to quantify the 6 metal elements in powders and water decoctions of raw and processed pyrites. The working conditions of ICP-AES were set as follows: sampler system was pneumatic atomizer; power was $1.3 \mathrm{~kW}$; cooling gas was Ar at $15 \mathrm{~L} \mathrm{~min}^{-1}$; plasma gas was Ar at $0.2 \mathrm{~L} \mathrm{~min}^{-1}$; carrier gas was Ar at $0.8 \mathrm{~L} \mathrm{~min}^{-1}$; sample pump flow velocity was $1.5 \mathrm{~mL}$ $\min ^{-1}$; flush time was $20 \mathrm{~s}$; integration time was $5 \mathrm{~s}$; detection wavelength was $259.939 \mathrm{~nm}$ for $\mathrm{Fe}, 193.696 \mathrm{~nm}$ for As, 206.200 $\mathrm{nm}$ for $\mathrm{Zn}, 220.353 \mathrm{~nm}$ for $\mathrm{Pb}, 257.610 \mathrm{~nm}$ for $\mathrm{Mn}$, and $327.393 \mathrm{~nm}$ for $\mathrm{Cu}$.

Digestion of raw and processed pyrite powders. The obtained raw or processed pyrite powders $(0.1 \mathrm{~g}$ each $)$ were put into a tetrafluoroethylene tank, into which $2 \mathrm{~mL}$ of $\mathrm{HNO}_{3}, 6 \mathrm{~mL}$ of $\mathrm{HCl}$ and $2 \mathrm{~mL}$ of $\mathrm{HF}$ were then added. The tanks were put into a microwave oven for digestion. The gradient digestion conditions were set as follows: 0-5 $\mathrm{min}, 120{ }^{\circ} \mathrm{C}, 15 \mathrm{MPa}$; 5-10 $\mathrm{min}$, $160{ }^{\circ} \mathrm{C}, 20 \mathrm{MPa}$; $10-25 \mathrm{~min}, 190{ }^{\circ} \mathrm{C}, 25 \mathrm{MPa}$; $25-35 \mathrm{~min}, 210^{\circ} \mathrm{C}$, $35 \mathrm{MPa}$.

Preparation of raw and processed pyrite decoctions. Raw or processed pyrite granules, $50.0 \mathrm{~g}$ each, were soaked in $250 \mathrm{~mL}$ of distilled water for $1 \mathrm{~h}$, decocted for $40 \mathrm{~min}$ before filtration, added $200 \mathrm{~mL}$ of distilled water and decocted for another $30 \mathrm{~min}$. The filtrates of decoctions of raw and processed pyrites were independently collected, mixed, concentrated and adjusted to the final volume of $50 \mathrm{~mL}$.

\section{Cell experiments}

Preparation of raw and processed pyrite aqueous extracts. Raw or processed pyrite granules, $150.0 \mathrm{~g}$ each, were soaked in $800 \mathrm{~mL}$ of distilled water and decocted for $60 \mathrm{~min}$ before filtration. Another $800 \mathrm{~mL}$ of distilled water was added into the residue and decocted for $60 \mathrm{~min}$ before filtration. The filtrates were collected and concentrated to a level that $1 \mathrm{~mL}$ of solution was equivalent to $0.75 \mathrm{~g}$ of raw or processed pyrite. The final solutions were stored in a $4{ }^{\circ} \mathrm{C}$ refrigerator before use.

Preparation of drug-containing sera. Thirty male SpragueDawley rats weighing 180-220 g, which were provided by Experimental Animal Center of Nanjing University of Chinese Medicine, were randomly divided into 3 groups $(n=10)$. These rats were housed with free access to laboratory food and water, but deprived of food for $12 \mathrm{~h}$ with water available prior to the experiment. One group was orally administrated with $0.9 \%$ saline as blank control. The other two groups were given raw and processed pyrite decoctions at the same dose of $1.0 \mathrm{~mL} 100$ 
$\mathrm{g}^{-1}$ body weight respectively. All groups were orally administrated with the decoctions twice a day for 3 successive days and once on the 4 th day. On the 4 th day, the rats were anesthetized with $10 \%$ chloral hydrate $\left(0.3 \mathrm{~g} \mathrm{~kg}^{-1}\right.$ body weight $)$ through intraperitoneal injection $1 \mathrm{~h}$ after oral administration of decoction. Then serum samples were collected from the abdominal aorta and centrifuged at $3600 \mathrm{rpm}$ for $10 \mathrm{~min}$. Each supernatant was harvested and inactivated in $56{ }^{\circ} \mathrm{C}$ water bath for $30 \mathrm{~min}$ as drug-containing serum. The resulting serum samples were filtered sterilely and stored in a $-80^{\circ} \mathrm{C}$ refrigerator before use.

Cell culture. Primary osteoblasts were isolated from the calvarium of Sprague Dawley rat pups. After sacrifice, the calvarium was harvested immediately and all adhering soft tissues were removed. The cleared calvarium was exposed to $0.25 \%$ trypsin for $30 \mathrm{~min}$ of primary digestion. Then, the calvarium was washed 3 times with phosphate buffer saline, cut into pieces of $1 \mathrm{~mm}^{3}$ and further digested with $0.1 \%$ collagenase II for $2 \mathrm{~h}$. The cells were collected by centrifugation, and washed with $\alpha$-modified Eagle's medium (MEM) supplemented with $10 \%$ fetal bovine serum (FBS). The supernatant was removed and the bottom cells were cultured in $\alpha$-MEM which was supplemented with $15 \%$ FBS and $1 \%$ penicillin/ streptomycin. The cells were seeded in $25 \mathrm{~cm}^{2}$ cell culture flask at the density of $1 \times 10^{5}$ cells per $\mathrm{cm}^{3}$ and cultured in humidified atmosphere of $5 \% \mathrm{CO}_{2}$ at $37{ }^{\circ} \mathrm{C}$ for several days until $80 \%$ confluence was reached. The cells were harvested with $0.25 \%$ trypsin-EDTA solution and seeded in tissue culture plates for various assays. All the above procedures were performed under sterile conditions.

Cell proliferation assay. Cell proliferation was evaluated by cell counting kit-8 (CCK-8). Osteoblast suspension $(100 \mu \mathrm{L})$ was plated in 96-well plates, $10^{4}$ cells each well. After $24 \mathrm{~h}$ of culture, the cells in various wells were treated with drug-containing serum samples which were mixed with nutrient solutions at concentrations of $2 \%, 5 \%$ and $10 \%$. FBS was set as blank control. After $24 \mathrm{~h}$ of incubation, $10 \mu \mathrm{L}$ of CCK- 8 was added to each well and incubated at $37^{\circ} \mathrm{C}$ for another $2 \mathrm{~h}$. The plate was read at $450 \mathrm{~nm}$ by using a microplate reader (Bio-Rad, Model 550).

$$
\begin{gathered}
\text { Proliferation rate }(\%)=\left[\left(\mathrm{OD}_{\text {sample }}-\mathrm{OD}_{\text {blank }}\right) /\left(\mathrm{OD}_{\text {control }}-\right.\right. \\
\left.\left.\mathrm{OD}_{\text {blank }}\right)-1\right] \times 100 \%
\end{gathered}
$$

Measurement of ALP activity. ALP is one of the early markers for osteoblast differentiation. Primary osteoblasts were seeded at the density of $10^{5}$ cells per well in 24 -well plates with $10 \%$ FBS. After incubation for $24 \mathrm{~h}$, the cells in various wells were treated by drug-containing serum mixed with nutrient solutions at concentrations of $2 \%, 5 \%$ and $10 \%$. ALP activity was measured by using an ALP assay kit (Beyotime, Shanghai, China). After $72 \mathrm{~h}$ of incubation, $20 \mu \mathrm{L}$ of supernatant was transferred to a 96-well plate. ALP activity of the supernatant was measured in accordance with the kit's instructions. The plate was read at $405 \mathrm{~nm}$ by using a microplate reader (Bio-Rad, Model 550).
Determination of mineralized nodules with alizarin red staining. Calcium accumulations in osteoblasts were detected by alizarin red staining. Osteoblasts were seeded in 24-well plates, $10^{5}$ cells each well. After incubation for $24 \mathrm{~h}$, the cells in various wells were treated with drug-containing sera at concentrations of $2 \%, 5 \%$ or blank serum. Meanwhile, $10 \%$ FBS was set as blank control. After culture for 14 days, the plates were stained according to the instruction of alizarin red staining kit and photographed under an inverted microscope to count mineralized nodules. To quantify the stained nodules, the stain was solubilized with $1 \mathrm{~mL}$ of $100 \mathrm{mmol} \mathrm{L}^{-1}$ hexadecylpyridinium chloride for $1 \mathrm{~h}$ at room temperature. ${ }^{9}$ An aliquot of $150 \mu \mathrm{L}$ solubilized stain was transferred to a 96-well plate, and the plate was read at $570 \mathrm{~nm}$ by using a microplate reader (Bio-Rad, Model 550).

\section{Statistical analysis}

All tests were conducted in triplicate independently. Statistical analyses were carried out with SPSS 16.0 software using one-way analysis of variance and student's $t$-test. All data were expressed as mean \pm standard deviation. Difference was considered statistically significant when $P<0.05$.

\section{Results and discussion}

Pyrite has been used to treat fracture healing problems for hundreds of years in China. ${ }^{\mathbf{1 0} 11}$ With some toxic components, it is commonly calcined before clinical use to enhance efficacy and to reduce toxicity. In this study, a calcination-quenching method was employed to process raw pyrite. The quality of processed pyrite is affected by calcination temperature, time and quenching time. ${ }^{12}$ Our group has previously reported that the optimum processing procedure was $2 \mathrm{~h}$ of calcination at $600{ }^{\circ} \mathrm{C}$ and quick quenching once. Herein, processed pyrite was prepared under the optimized conditions.

The surface properties, mineral phase characteristics and mineralogical compositions of raw and processed pyrites were compared. According to the TCM processing theory, calcination and quenching can make processed pyrite fragile, easily crushable and readily dissoluble in decoction. Microstructural observation showed that raw pyrite was dense internally whereas processed pyrite was loose inside. Metal elements in processed pyrite were more prone to release and dissolution into decoction. Mineralogical characteristics analysis suggested that the lattice form of raw pyrite changed after processing. Phase composition was mainly converted into pyrrhotite and some hematite after being calcined at $600{ }^{\circ} \mathrm{C}$ for $2 \mathrm{~h}$ and quenched quickly in vinegar.

\section{Microstructure of pyrite}

The SEM images of raw and processed pyrites are shown in Fig. 1 and 2. Fig. 1 shows that the particle size of raw pyrite exceeds that of processed pyrite. Fig. 2 exhibits that raw pyrite has a compact interior, with sediments in the middle and exterior. In contrast, processed pyrite has a loose interior, with many honeycombs, bubble-like protrusions and faults in the 

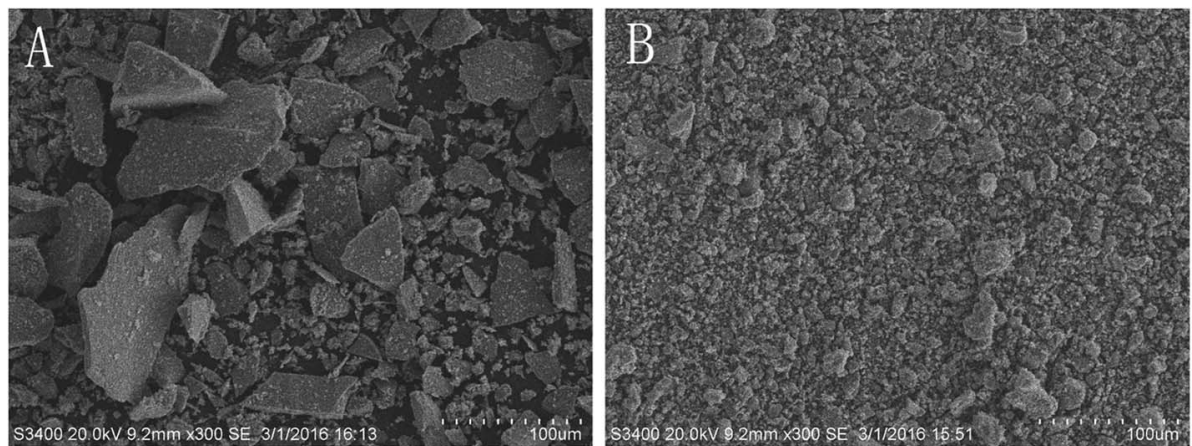

Fig. 1 SEM spectra of surface features of raw (A) and processed (B) pyritum (scanning radius of $100 \mu \mathrm{m}$ ).
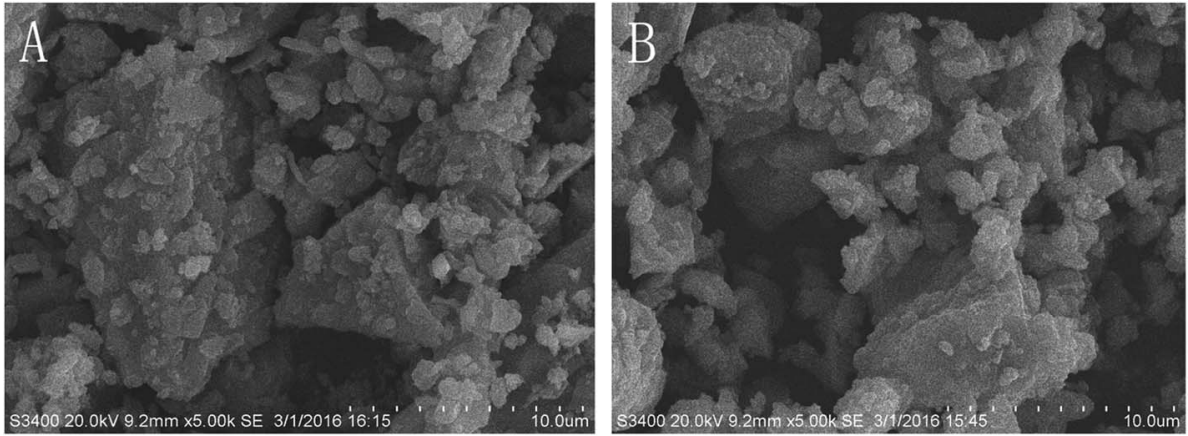

Fig. 2 SEM spectra of surface features of raw (A) and processed (B) pyritum (scanning radius of $10 \mu \mathrm{m}$ ).

exterior. Therefore, processed pyrite was obviously more fragile than raw pyrite, allowing easy crushing and dissolution in decoction.

\section{Phase compositions of pyrite}

Powder XRD was employed to analyze the mineralogical composition changes of pyrite (Fig. 3). The obtained standard

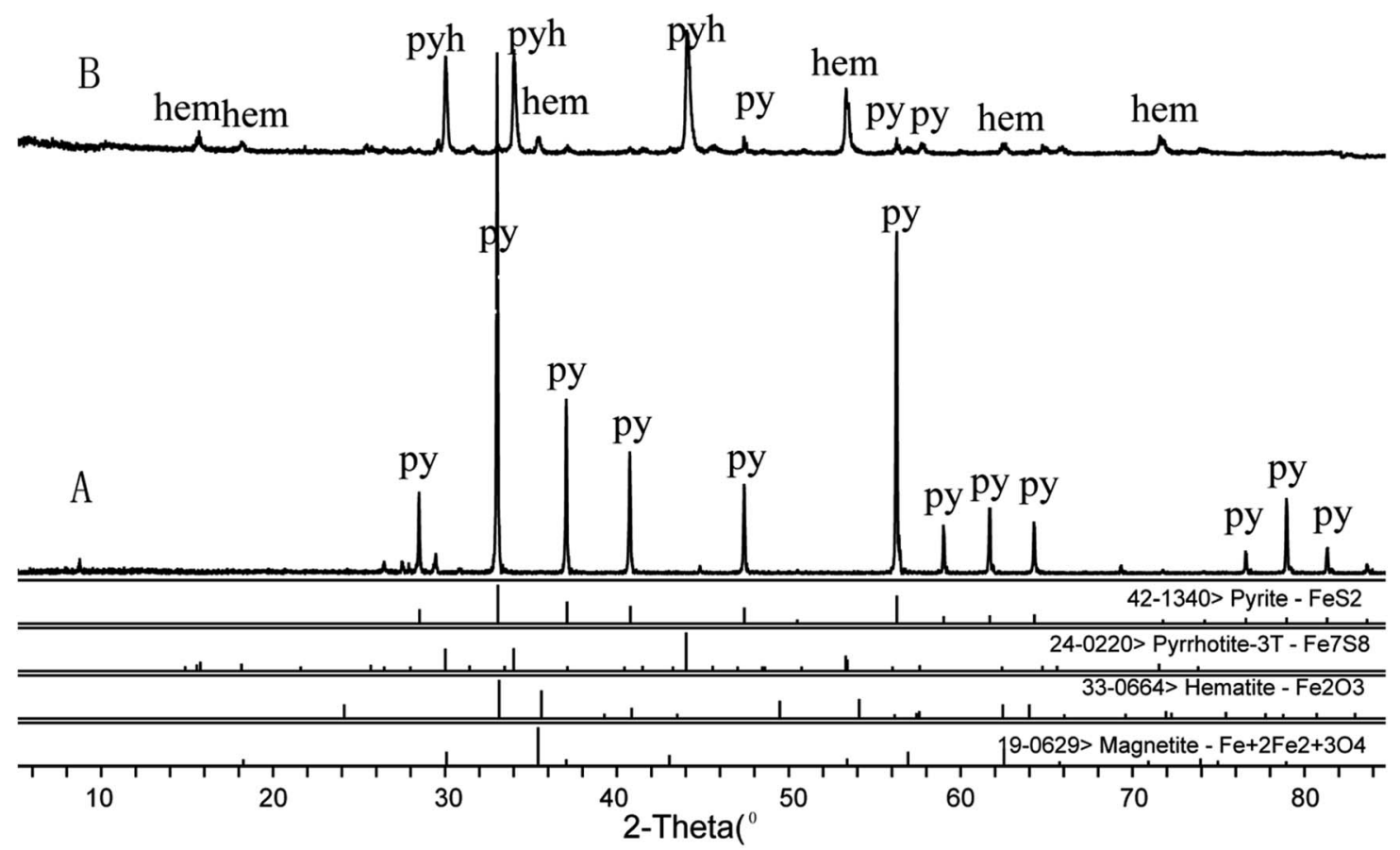

Fig. 3 X-ray diffraction patterns showing the phase change of raw pyritum (A) and processed pyritum (B) p: pyrite, pyh: pyrrhotite, hem: hematite. 
XRD data were further processed by X'Pert HighScore Plus software for semi-quantitative phase analysis. The calculated phase compositions of raw and processed pyrites are presented in Table 1. The main component of raw pyrite was $\mathrm{FeS}_{2}$ which changed to pyrrhotite, hematite and a small amount of $\mathrm{FeS}_{2}$ after processing at $600{ }^{\circ} \mathrm{C}$ for $2 \mathrm{~h}$ and quenching in vinegar. In contrast, the main component of processed pyrite was pyrrhotite, accounting for $87 \%$ of all phase components. Hematite and $\mathrm{FeS}_{2}$ only accounted for about $6.2 \%$ and $4.6 \%$ respectively.

\section{FTIR analysis of pyrite}

It is well-documented that the IR absorption peaks of $\mathrm{FeS}_{2}$ and $\mathrm{Fe}_{3} \mathrm{O}_{4}$ are located at around $420 \mathrm{~cm}^{-1}$ and $565 \mathrm{~cm}^{-1}$ respectively, those of $\mathrm{Fe}_{7} \mathrm{~S}_{8}$ are at around $470 \mathrm{~cm}^{-1}$ and $540 \mathrm{~cm}^{-1}$, and those of $\mathrm{Fe}_{2} \mathrm{O}_{3}$ are at around $480 \mathrm{~cm}^{-1}, 619 \mathrm{~cm}^{-1}, 794 \mathrm{~cm}^{-1}$ and $1090 \mathrm{~cm}^{-1}$. As presented in Fig. 4, the absorption peak of raw pyrite is located at about $411 \mathrm{~cm}^{-1}$, suggesting that the main

Table 1 Semi-quantitative phase compositions of raw and processed pyrites

\begin{tabular}{lccccc}
\hline \multirow{5}{*}{ Processing method } & \multicolumn{5}{c}{ Phase composition (\%) } \\
\cline { 2 - 6 } & $\mathrm{FeS}_{2}$ & $\mathrm{Fe}_{7} \mathrm{~S}_{8}$ & $\mathrm{Fe}_{3} \mathrm{O}_{4}$ & $\mathrm{Fe}_{2} \mathrm{O}_{3}$ & $\mathrm{SiO}_{2}$ \\
\hline Raw & 92.3 & - & - & - & 7.6 \\
Processed & 4.6 & 87.0 & 6.2 & 2.1 & -
\end{tabular}

phase was $\mathrm{FeS}_{2}$. The absorption peaks of processed pyrite are at $426 \mathrm{~cm}^{-1}, 469 \mathrm{~cm}^{-1}, 539 \mathrm{~cm}^{-1}$ and $1094 \mathrm{~cm}^{-1}$, corresponding to $\mathrm{Fe}_{7} \mathrm{~S}_{8}, \mathrm{Fe}_{3} \mathrm{O}_{4}$ and $\mathrm{Fe}_{2} \mathrm{O}_{3}$ respectively. The results are consistent with those of XRD.

\section{Magnetic characteristics}

The magnetic characteristics of raw and processed pyrites are presented in Fig. 5. The saturation magnetization increases with enhanced additional magnetic field. When the additional magnetic field intensity increases to $10^{4}$ Oe, the magnetic strength is saturated, also known as saturation magnetization. Saturation magnetization is an important parameter of magnetic characteristics, which is related to the type of ferromagnetic material. The saturation magnetization of raw pyrite

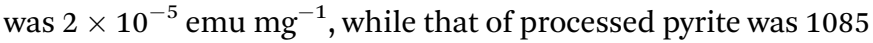
$\times 10^{-5} \mathrm{emu} \mathrm{mg}^{-1}$. The magnetic susceptibilities follow a descending order of $\mathrm{Fe}_{3} \mathrm{O}_{4}>\mathrm{Fe}_{7} \mathrm{~S}_{8}>\mathrm{Fe}_{2} \mathrm{O}_{3}>\mathrm{FeS}_{2}$. Considering XRD results simultaneously, the main phase component of raw pyrite was $\mathrm{FeS}_{2}$, but processed pyrite was mainly composed of $\mathrm{Fe}_{7} \mathrm{~S}_{8}$, with small amounts of $\mathrm{FeS}_{2}, \mathrm{Fe}_{3} \mathrm{O}_{4}$ and $\mathrm{Fe}_{2} \mathrm{O}_{3}$.

\section{Iron and metal elements in pyrite}

ICP-AES has been widely used for trace element analysis due to low detection limit, high precision and multi-elements determination. In this study, the contents of 6 metal elements in pyrite powders and decoctions were determined (Tables 2 and 3). Fe, $\mathrm{Zn}$ and $\mathrm{Mn}$, especially $\mathrm{Zn}$, increased significantly in the

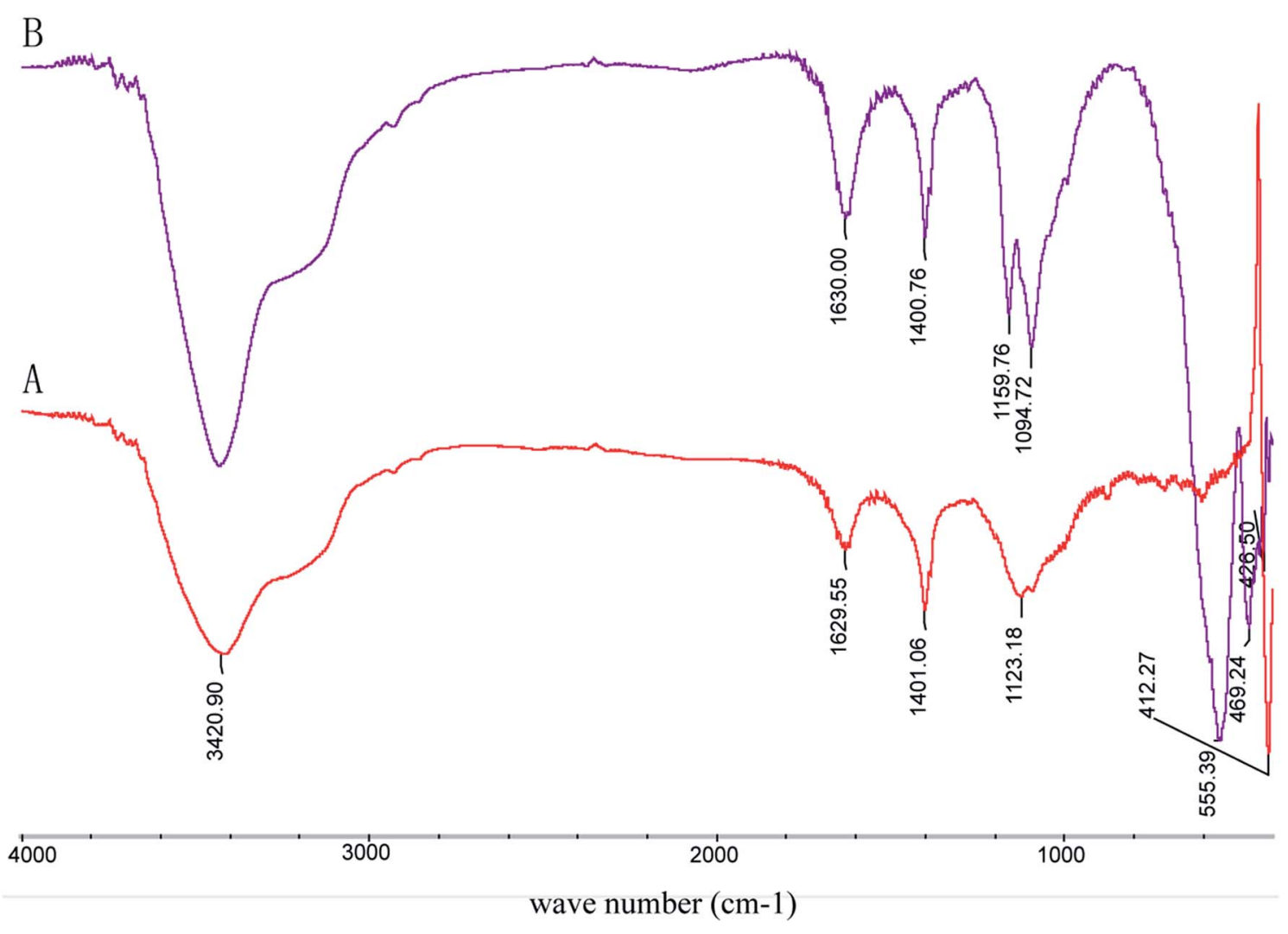

Fig. 4 The infrared spectrum of raw pyritum (A) and processed pyritum (B). 

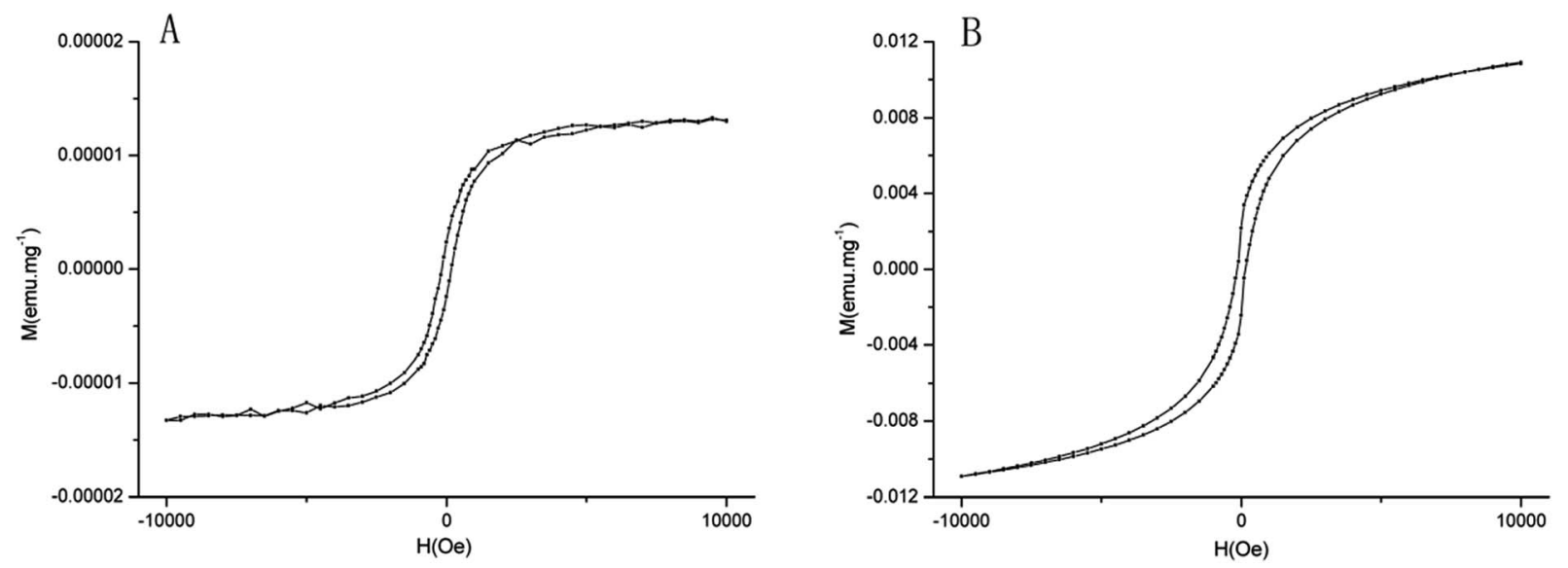

Fig. 5 Hysteresis loop of raw pyrite (A) and processed pyrite (B).

Table 2 Trace element concentrations of raw and processed pyrites

\begin{tabular}{llrrrrr}
\hline & \multicolumn{7}{l}{ Element $\left(\mathrm{mg} \mathrm{kg}^{-1}\right)$} & & & \\
\cline { 2 - 7 } Sample (pyrite) & $\mathrm{Fe}$ & $\mathrm{Zn}$ & $\mathrm{Cu}$ & $\mathrm{Mn}$ & \multicolumn{1}{c}{ As } & \multicolumn{1}{c}{$\mathrm{Pb}$} \\
\hline Raw & 473400 & 14.2 & 8.3 & 31.5 & 89.5 & 52.5 \\
Processed & 568740 & 144.3 & 13.3 & 97.5 & 4.5 & 61.5
\end{tabular}

Table 3 Trace element concentrations in raw and processed pyrite decoctions $^{a}$

\begin{tabular}{lrrrrrl}
\hline & \multicolumn{2}{l}{ Element $\left(\mathrm{mg} \mathrm{L}^{-1}\right)$} \\
\cline { 2 - 7 } Sample (pyrite) & \multicolumn{1}{c}{$\mathrm{Fe}$} & $\mathrm{Zn}$ & $\mathrm{Cu}$ & $\mathrm{Mn}$ & $\mathrm{As}$ & $\mathrm{Pb}$ \\
\hline Raw & 506.56 & 6.08 & $\mathrm{ND}$ & 14.59 & $\mathrm{ND}$ & ND \\
Processed & 18096.19 & 15.81 & $\mathrm{ND}$ & 15.19 & $\mathrm{ND}$ & 19.00 \\
${ }^{a}$ ND means not detected. & & & & &
\end{tabular}

powder and decoction of processed pyrite as a result of calcination and quenching, whereas the content of As in powder decreased sharply. $\mathrm{Pb}$ and $\mathrm{Cu}$ in pyrite hardly changed after processing. Gao et al..$^{13}$ found that the concentrations of $\mathrm{Fe}, \mathrm{Zn}$, $\mathrm{Mn}, \mathrm{Mg}, \mathrm{Ca}, \mathrm{Co}$ and $\mathrm{Ni}$ all increased in various degrees but $\mathrm{Pb}$ decreased in processed pyrite decoction. Similarly, $\mathrm{Tie}^{14}$ reported that the content of As in processed pyrite was about 1/10 of that in raw pyrite.

As is a poisonous element that exists in pyrite. It can directly harm human brain cells and cause congenital shallow of the cerebral sulcus. Hwang et al. ${ }^{6}$ found that arsenopyrite did not disappear even after five processing cycles at $450{ }^{\circ} \mathrm{C}$, but vanished after only one processing cycle at $650{ }^{\circ} \mathrm{C}$, which may be ascribed to the oxidation of arsenic compound at higher temperature and then dissolution in vinegar.

The contents of $\mathrm{Cu}$ and $\mathrm{As}$ in the decoctions of raw and processed pyrites were under detection limits. The content $\mathrm{of} \mathrm{Pb}$ in the decoction of processed pyrite reached $0.01900 \mathrm{mg} \mathrm{g}^{-1}$ which was higher than that of raw pyrite decoction. Nevertheless, according to the standard of World Health Organization, the maximum permissible daily intake of $\mathrm{Pb}$ should be less than $0.214 \mathrm{mg}$ for adults. Considering that the maximum daily dose for pyrite is $10.0 \mathrm{~g}$ for adults, ${ }^{1}$ the actual intake of $\mathrm{Pb}$ is only $0.19 \mathrm{mg}$, as a safe dose accordingly.

\section{Morphological observation of osteoblasts}

Fig. 6 exhibits that osteoblasts are spherical and suspending in the medium. Within $24 \mathrm{~h}$ of incubation, the cells grew logarithmically and spread on the well bottom (Fig. 6a). Matured osteoblasts grew against the wall of flask and displayed fibroblastic morphology with many projections. The cells were generally triangular or polygonal monocytes, containing 1-3 nucleoli each (Fig. 6b). Overlapped cell growth caused collagen synthesis, calcium deposition, and finally formation of mineralized nodules (Fig. 6c). After incubation for 15 days, the cells formed opaque mineralized nodules which were stained dark red in the center with alizarin red (Fig. 6d).

\section{Effects of various drug-containing sera on osteoblast proliferation}

Osteoblast proliferation was examined by the MTT method, using $10 \%$ FBS as blank control. The activities of sera containing raw and processed pyrites as well as blank serum against osteoblast proliferation are presented in Fig. 7. Sera containing $2 \%$ and $5 \%$ processed pyrite exhibited high activities $(100 \%$ and $120 \%$ respectively). The activities of sera containing raw pyrite at concentrations of $2 \%$ and $5 \%$ were $80 \%$ and $100 \%$, respectively. There was no significant difference among the three groups. In short, sera containing raw and processed pyrites had no effect on osteoblast proliferation activity.

\section{Effect of drug-containing serum on ALP activity}

ALP is synthesized and secreted by osteoblasts. The effects of various drug-containing serum samples on ALP activity were assessed (Fig. 8). The serum containing $2 \%$ raw pyrite barely affected ALP activity compared to blank serum did, whereas processed pyrite-containing serum significantly enhanced the activity compared to blank serum $(p<0.001)$ and raw pyrite- 


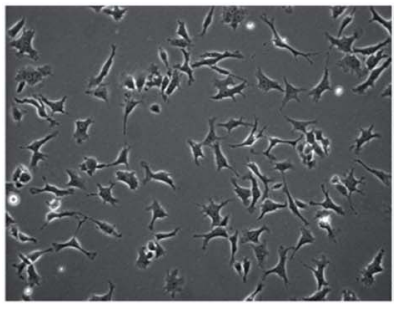

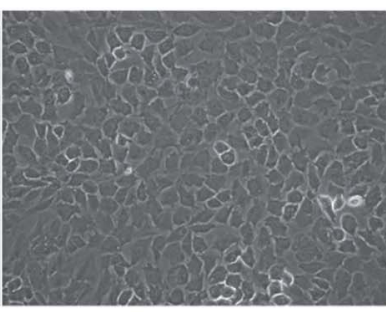

b

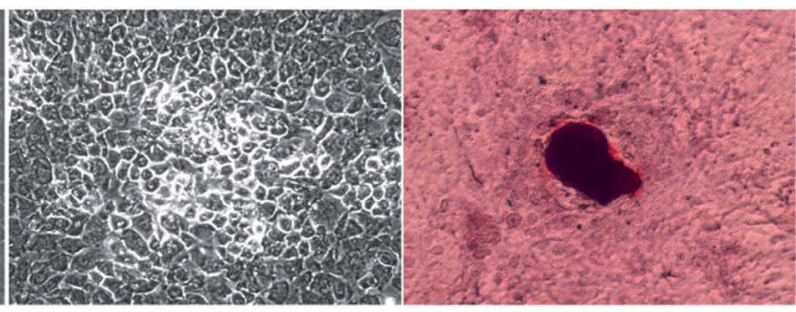

$\mathrm{c}$

d

Fig. 6 Morphological changes of osteoblasts in rats under inverted phase contrast microscope at different culture times. (a) 1 day; (b) 5 days; (c) 10 days; (d) 15 days.

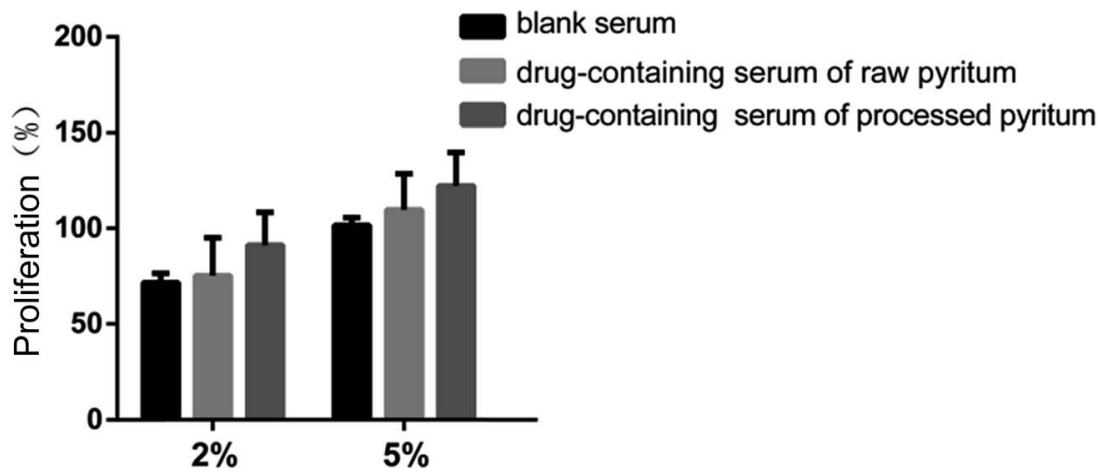

Fig. 7 Effects of drug-containing serum on osteoblasts proliferation after treating $48 \mathrm{~h}$.

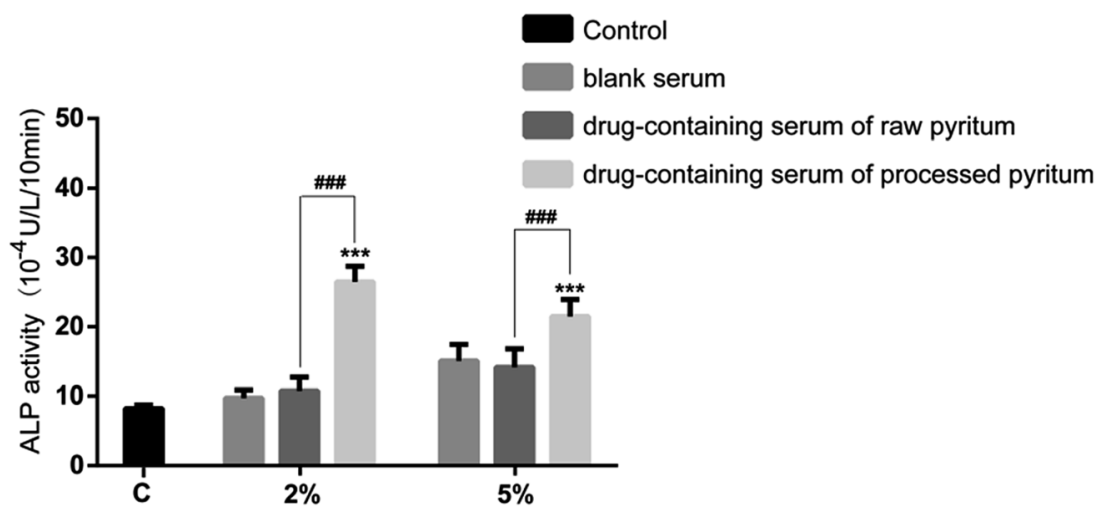

Fig. 8 Effects of various drug-containing serum on osteoblasts ALP activity. Note: data is presented as mean \pm SD in three parallel experiments. Significance: vs. blank serum: ${ }^{* * *} p<0.001$; vs. drug-containing serum of raw pyritum: ${ }^{\# \#} p<0.001$.

containing serum did $(p<0.001)$. At the concentration of $5 \%$, the ALP activity was similar between raw pyrite-containing serum and blank serum, but processed pyrite-containing serum significantly augmented the activity compared to blank serum $(p<0.001)$ and raw pyrite did $(p<0.001)$. Collectively, processed pyrite but not raw pyrite remarkably boosted the ALP activity of osteoblasts.

Effects of various drug-containing sera on the formation of osteoblast mineralized nodules

After culture for 2 weeks, mineralized nodules formed in the colony center of osteoblasts, which were stained orangish red by alizarin red (Fig. 9a). Small mineralized nodules were sparsely distributed in blank control and blank serum. When sera containing $2 \%$ and $5 \%$ raw or processed pyrite were added to the culture medium, more mineralized nodules formed than those of blank serum. The mineralized nodule density of processed pyrite exceeded that of raw pyrite. According OD values (Fig. 9b), at the concentration of $2 \%$, processed pyrite-containing serum formed more mineralized nodules than raw pyrite-containing serum $(p<0.05)$ and blank serum did $(p<0.01)$. At the concentration of $5 \%$, sera containing raw pyrite $(p<0.01)$ and processed pyrite $(p<0.001)$ formed more mineralized nodules than blank serum did, and the processed product was better than the raw material $(p<0.001)$. Accordingly, sera containing 


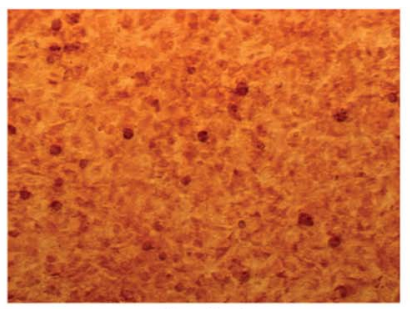

Control
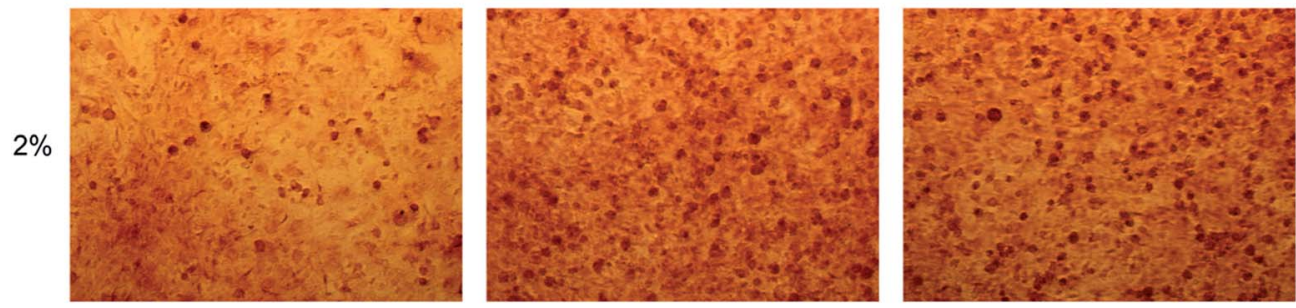

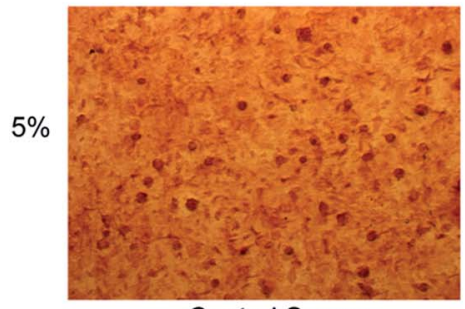

Control Serum

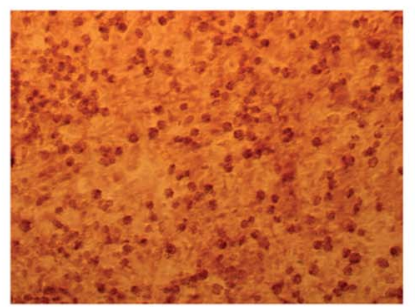

Raw group

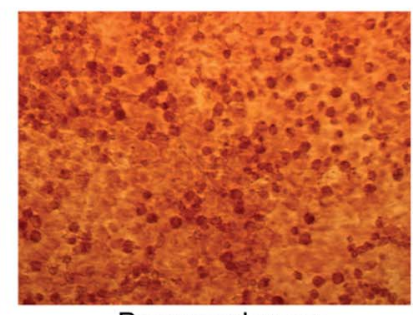

Processed group

b

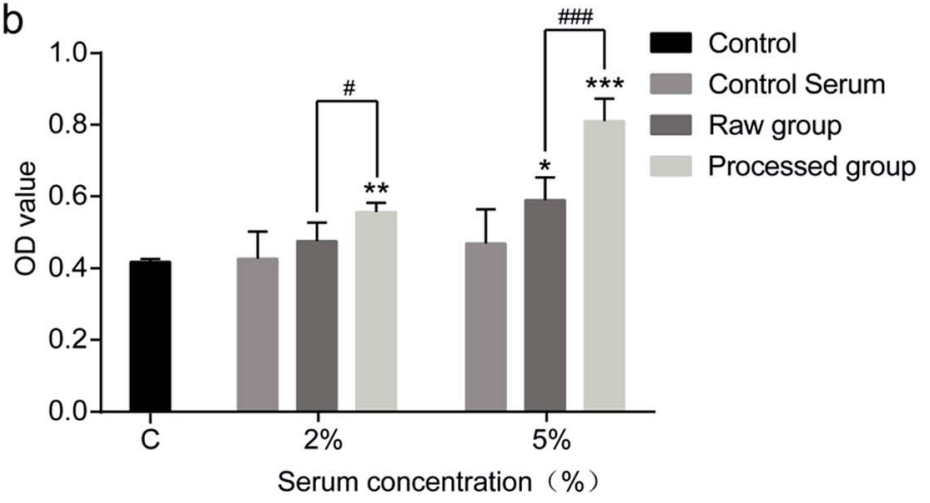

Fig. 9 Effect of various drug-containing serum on the formation of osteoblast mineralized nodules. Note: data is presented as mean \pm SD in three parallel experiments. Significance: vs. control serum: ${ }^{*} p<0.05, * * p<0.01,{ }^{* * *} p<0.001$; vs. raw group: ${ }^{\#} p<0.05$, ${ }^{\# \# \#} p<0.001$.

both raw and processed pyrites were able to promote the formation of mineralized nodules, with the latter being more effective.

This study compared the changes of osteoblast proliferation, differentiation and mineralization-stimulating activities of sera containing raw and processed pyrites, unlike previous studies only focusing on promoted fracture healing of animals. Xu et al. ${ }^{15}$ reported that the contents of $\mathrm{Fe}, \mathrm{Zn}, \mathrm{Mn}$ and $\mathrm{Cu}$ in callus were higher in pyrite-administrated group. As a bank for metal elements, pyrite contains $\mathrm{Fe}, \mathrm{Zn}, \mathrm{Mn}, \mathrm{Mg}$, Ni and so on. These elements play important roles in human body growth and tissue repair. In this study, the contents of Fe and $\mathrm{Zn}$ in the processed pyrite decoction were about 36- and 2.5-fold those of the raw one respectively.

Fe is a vital element. Bone remodeling is susceptible to changes in iron homeostasis, and both iron deficiency and iron excess affect bone health in humans and rodents. ${ }^{16}$ Iron is an essential element for the formation of hemoglobin. Previous in vitro studies have revealed that excess iron influenced osteoblastic metabolism, thus increasing intracellular ROS level by affecting oxidative stress, ${ }^{17-19}$ and deficiency of iron influenced the activity of ribonucleotide reductase. ${ }^{20}$ Dietary iron is positively associated with bone mineral density in healthy postmenopausal women. ${ }^{21}$ The rats with iron deficiency have low bone mass due to reduced bone turnover. ${ }^{22}$ Iron can enhance the proliferation and differentiation of osteoblasts, and Wnt5a has been identified as a key target for the pro-osteogenic effects of iron chelation on osteoblast progenitors. ${ }^{16}$ Iron also affects the expressions of RANKL/OPG genes and proteins in osteoblasts. ${ }^{23}$ However, the mechanism by which iron affects the ALP activity and mineralization activity of osteoblasts remains unclear, which may be the direction of future research. As 
a cofactor of ALP, zinc is also involved in the stimulation of bone formation, ALP activity, and mineralization in both calvarial organ cultures and osteoblast cultures. ${ }^{24,25}$

We found that processed pyrite-containing serum enhanced ALP activity more effectively than raw pyrite-containing serum and blank serum did. Besides, it also promoted osteoblast mineralization. Thus, Fe and $\mathrm{Zn}$ in processed pyrite-containing serum were beneficial to osteoblast on ALP activity. These results not only proved the importance of processing to raw pyrite, but also provided scientific evidence for the efficacy and safety of clinical use of processed pyrite.

However, this study still has some limitations. We only determined trace elements in powders and decoctions, but the mechanisms for their influences on osteoblast activity have not been clarified. Furthermore, traditional processing technology has no standard for the supply of vinegar. We herein found that vinegar affected the contents of trace elements in processed pyrite, so it is necessary to research the standardization of vinegar.

\section{Conclusions}

In summary, pyrite was loose inside, and the main component of pyrite changed from $\mathrm{FeS}_{2}$ to a mixture of $\mathrm{FeS}_{2}, \mathrm{Fe}_{7} \mathrm{~S}_{8}, \mathrm{Fe}_{3} \mathrm{O}_{4}$ and $\mathrm{Fe}_{2} \mathrm{O}_{3}$ after processing. The contents of $\mathrm{Fe}$ and $\mathrm{Zn}$ in processed pyrite powder and their dissolution in decoction were significantly higher than those in raw ones. Though the content of $\mathrm{Pb}$ in processed pyrite decoction was higher than that of raw pyrite decoction, it was within the maximum permissible daily intake. Processed pyrite-containing serum increased osteoblast ALP activity and promoted the formation of mineralized nodules compared to raw pyrite-containing serum and blank serum did.

\section{Live subject statement}

All experiments were performed in compliance with the Guidance Suggestions for the National Institutes for the Care and Use of Laboratory Animals (Laboratory Animal Management Regulations). The study was approved by the ethics committee of Nanjing University of Chinese Medicine.

\section{Acknowledgements}

This research was supported by NSFC (grant number 81373970) and Jiangsu Qinglan Project (2014).

\section{References}

1 National Pharmacopoeia Committee, Pharmacopoeia of People's Republic of China, China Medical Science and Technology Press, Beijing, 2015, p. 141.

$2 \mathrm{X}$. He, The Chinese Materia Medica, Beijing University of Traditional Chinese Medicine, Academy Press, Beijing, 1998, p. 3.
$3 \mathrm{H} . \mathrm{Wu}$ and C. J. Hu, The Processing of Chinese Material, Press of People's Medical Publishing House, Beijing, China, 2012, p. 225.

4 T. Z. Jia, Processing of Chinese Herbal Medicine, Shanghai Scientific and Technical Publishers, Shanghai, 2008, p. 220.

5 S. Y. Jin and Q. Wang, Studies on Processing of Chinese Medicinal Yin pian and its Clinical Application, Press of Chemistry Industry, Beijing, 2004, p. 276.

6 J. Hwang, S. D. Hur and Y. B. Seo, Mineralogical and Chemical Changes in Pyrite after Traditional Processing for Use in Medicines, Am. J. Chin. Med., 2004, 32, 907.

7 I. Pountos, T. Georgouli, K. George and P. V. Giannoudis, Efficacy of minimally invasive techniques for enhancement of fracture healing: evidence today, Int. Orthop., 2010, 34, 3.

8 A. Schindeler, M. M. McDonald, P. Bokko and D. G. Little, Bone remodeling during fracture repair: the cellular picture, Semin. Cell Dev. Biol., 2008, 19, 459.

9 S. Yu, L. M. Yerges-Armstrong, Y. Chu, J. M. Zmuda and Y. Zhang, E2f1 effects on osteoblast differentiation and mineralization are mediated through up-regulation of frizzled-1, Bone, 2013, 56, 234.

10 Z. Quan, L. Wei, Y. Du, C. Li and H. Yang, Composition and thermal stability of traditional Tibetan mineral medicine calcitum, China J. Chin. Mater. Med., 2011, 36, 691.

11 Y. Lei, W. D. Li, J. S. Li, H. B. Wang and B. C. Cai, Far-infrared spectroscopy, X-ray diffraction, and thermogravimetric different thermal analyses on crude and processed Pyritum, Chin. Tradit. Herb. Drugs, 2011, 42, 275.

12 C. Gao, B. C. Cai, J. S. Li, W. D. Li and H. Cai, The research progress of natural copper, J. Nanjing Med. Univ., 2009, 25, 75.

13 C. Gao, W. D. Li, J. S. Li, X. Ding and B. C. Cai, Study on Changes of Microelement Content in Crude and Calcined Pyritum, J. Tradit. Chin. Med., 2009, 16, 47.

14 B. R. Tie, The study of As in pyrite, J. Chin. Mater. Med., 1991, 16, 341 .

15 A. X. Xu, Experiment and Clinical Study of Bone Fracture Healing Treated by Magnet and Pyritum, Dissertation of master degree, Shandong University of Traditional Chinese Medicine, 2009.

16 U. Baschant, M. Rauner, E. Balaian, et al., Wnt5a is a key target for the pro-osteogenic effects of iron chelation on osteoblast progenitors, Haematologica, 2016, 101, 1499.

17 M. Doyard, N. Fatih, A. Monnier, M. L. Island, M. Aubry, et al., Iron excess limits HHIPL-2 gene expression and decreases osteoblastic activity in human MG-63 cells, Osteoporosis Int., 2012, 23, 2435.

18 G. Y. Zhao, L. P. Zhao, Y. F. He, et al., A comparison of the biological activities of human osteoblast hFOB1.19 between iron excess and iron deficiency, Biol. Trace Elem. Res., 2012, 150, 487.

19 Y. F. He, Y. Ma, C. Gao, et al., Iron overload inhibits osteoblast biological activity through oxidative stress, Biol. Trace Elem. Res., 2013, 152, 292.

20 J. G. Messer, A. K. Kilbarger, K. M. Erikson and D. E. Kipp, Iron overload alters iron regulatory genes and proteins, down regulates osteoblastic phenotype, and is associated 
with apoptosis in fetal rat calvarias cultures, Bone, 2009, 45, 972.

21 R. Abraham, J. Walton, L. Russell, et al., Dietary determinants of post-menopausal bone loss at the lumbar spine: a possible beneficial effect of iron, Osteoporosis Int., 2006, 17, 1165.

22 S. Katsumata, R. Katsumata-Tsuboi, M. Uehara and K. Suzuki, Severe iron deficiency decreases both bone formation and bone resorption in rats, J. Nutr., 2009, 139, 238.

23 G. F. Li, Y. F. He, L. P. Zhao, et al., Effects of ferric ammonium citrate on the RANKL/OPG gene and protein expression of human osteoblasts, J. Bone Miner. Res., 2015, $02,143$.

24 H. J. Seo, Y. E. Cho, T. Kim, H. I. Shin and I. S. Kwun, Zinc may increase bone formation through stimulating cell proliferation, alkaline phosphatase activity and collagen synthesis in osteoblastic MC3T3-E1 cells, Nutr. Res. Pract., 2010, 4, 356.

25 M. Nagata and B. Lonnerdal, Role of zinc in cellular zinc traffickingand mineralization in a murine osteoblast-like cell line, J. Nutr. Biochem., 2011, 22, 172. 